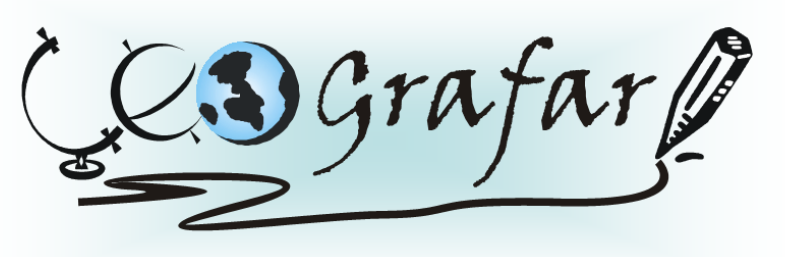

Revista Eletrônica do Programa de Pós-Graduação em Geografia - UFPR

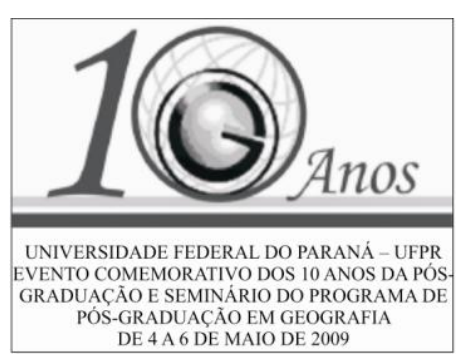

\title{
A TEORIA DOS REFÚGIOS FLORESTAIS: DISTRIBUIÇÃO E EVOLUÇÃO DAS PAISAGENS AO FIM DO PLEISTOCENO.
}

\author{
PEDRO AUGUSTO HAUCK DA SILVA ${ }^{1}$ \\ EVERTON PASSOS ${ }^{2}$
}

\section{LINHA DE PESQUISA: PAISAGEM E ANÁLISE AMBIENTAL}

O presente trabalho faz um esforço em realizar uma revisão sobre o estado da arte acerca da Teoria dos Refúgios Florestais, considerada um importante paradigma referente aos mecanismos e padrões de distribuição de floras e faunas da América Neotropical. Para tal, são reunidas informações numa vasta revisão bibliográfica sobre estudos paleogeográficos do Quaternário.

A idéia que embasa a Teoria é que flutuações climáticas da passagem para uma fase mais seca e fria durante o Pleistoceno terminal, a biota de florestas tropicais ficou retraída às exíguas áreas de permanência da umidade, a constituir os refúgios e sofrer, portanto, diferenciação resultante deste isolamento (VIADANA, 2000). A expansão destas manchas florestadas tropicais, em conseqüência da retomada da umidade do tipo climático que se impôs ao final do período seco e mais frio, deixou setores de maior diversidade e endemismos como evidência dos refúgios que atuaram no Pleistoceno terminal.

A razão da existência deste paleoclima mais seco e frio no período citado está relacionada, de acordo com Ab'Sáber (1992) com a glaciação de Würm-Wisconsin. Como conseqüência desta glaciação, os pólos confinaram muito mais água sob a forma de gelo resultando na redução do nível médio dos mares, deixando expostas grandes faixas de terras antes ocupadas pela água do mar. Devido este fenômeno, a corrente fria das Malvinas, neste período, chegava até o litoral sul do atual Estado da Bahia.

\footnotetext{
1 pedro@gentedemontanha.com

${ }^{2}$ Professor orientador
} 
As faixas de terra, que então afloravam, eram banhadas pela dita corrente marítima e se tornaram espaços com climas secos. Este quadro de mudanças climáticas durou alguns milhares de anos. Sendo que teve seu ápice de aridez, entre 12.000 e 18.000 mil anos atrás. Durante este período, segundo Ab'Sáber (1977), a cobertura vegetal higrófita sofreu um grande impacto com a perda de sua capacidade competitiva com as plantas xerófitas. Mesmo com considerável avanço das floras xerófitas em decorrência da aridificação e semiaridificação geral no continente sul-americano.

As floras higrófitas não foram extintas, pois caso contrário, não haveriam florestas e campos úmidos nas paisagens atuais. A biota úmida das Paisagens pleistocênicas ficaram retraídas em áreas exíguas onde mesmo durante o período máximo de aridez houve a manutenção da umidade e pluviosidade, isso devido as características morfológicas dos domínios de paisagens que comportam planaltos interiores, serras litorâneas e relevos residuais intra-depressionais.

Entretanto, hipóteses de extinções que vieram a ocorrer em decorrência da mudança climática não são descartadas, como no caso da extinção de alguns táxons da mega-fauna no período citado e a excepcional extinção tardia verificada em alguns lugares do nordeste brasileiro por decorrência da preservação de áreas refúgios e posterior desfragmentação de ditas paisagens (HAUCK, 2008).

Foram realizados trabalhos de campo em diversas regiões no Brasil onde verificou-se a existência de vegetação relictual deste período mais seco, além de formas na paisagem que retratam a paleogeografia do fim do Pleistoceno, como linhas de pedras subsuperficiais.

\section{REFERÊNCIAS BIBLIOGRÁFICAS:}

AB, SÁBER. A. N; Espaços ocupados pela expansão dos climas secos na América do Sul, por ocasião dos períodos glaciais quaternários. Paleoclimas (3).São Paulo. 1977

AB, SÁBER. A. N; A teoria dos refúgios: Origem e significado. Revista do Instituto florestal, Edição especial, São Paulo, março de 1992.

HAUCK, P. A Teoria dos Refúgios Florestais e sua relação com a extinção da megafauna Pleistocênica: Um estudo de caso. Estudos Geográficos (UNESP), v. 5, p. 121-134, 2008.

VIADANA, A.G. A teoria dos refúgios florestais aplicada ao estado de São Paulo. Edição do autor. Rio Claro, 2002.

Palavras chave: Teoria dos Refúgios Florestais, paleoclimas, paisagem 